L. PELEKIS I, O. KIRRET, I. TAURE, Zane PELEKIS, G. EGLIT, E. RAJAVEE, V. AHELIK

\title{
INSTRUMENTAL NEUTRON ACTIVATION ANALYSIS OF ESTONIAN ALUM SHALE AND SOME OTHER OIL SHALES
}

The aim of the present study is to apply an instrumental neutron activation analysis to the determination of major, minor and trace elemental abundances in the organic matter and mineral residue of the enriched alum shale.

The alum shale sample deposit was subjected to enrichment according to the following scheme.

Scheme of enrichment of Estonian alum shale

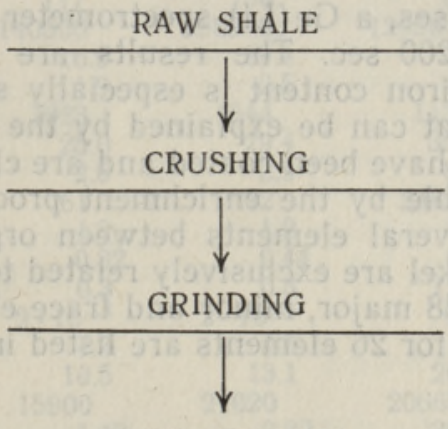

HYDROCYCLING

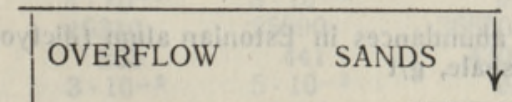

HYDROCYCLING

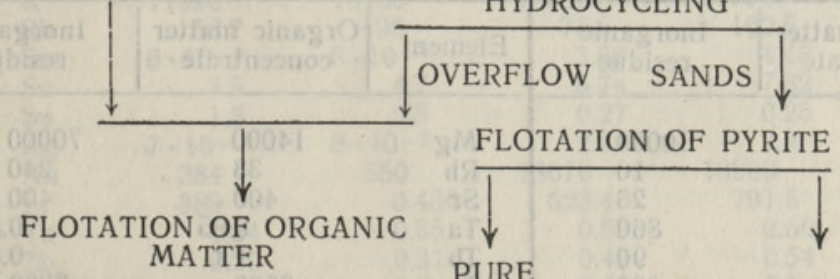

MATTER

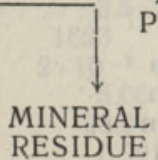

PYRITE

FLOTATION

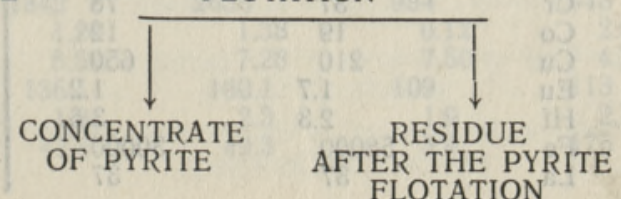




\section{Enriched products in Estonian alum shale}

Abundance of the organic matter in raw shale $17.3 \%$

\begin{tabular}{lc} 
Concentrate of & organic matte \\
Yield & 27.9 \\
Abundance & 46.7 \\
Recovery & 75.3 \\
\multicolumn{1}{r}{ Concentrate of pyrite, \% } \\
Yield & 16.1 \\
Abundance & 32.0 \\
Recovery & 83.6
\end{tabular}

Mineral residue, $\%$ 44.6

10.7

Quartz, \%

11.4

0.6

1.1

The determination of major, minor and trace elemental abundances in alum shale by the instrumental neutron activation method has been reported in $\left[{ }^{1,2}\right]$. The organic matter concentrate and mineral residue obtained by enriching alum shale was examined by the above-mentioned method at the Institute of Physics, the Latvian SSR Academy of Sciences. The experiments were carried out in a nuclear reactor at a flux density of $(1-3) \cdot 10^{13} \mathrm{n} / \mathrm{cm}^{2}$ and under the analysis conditions described in $\left[{ }^{2}\right]$.

The radiation time in vertical channels was $70 \mathrm{~h}$. After a 3-day cooling the samples and standards were repacked into polyethylene bags and analyzed for the first time, using a semiconductor $\gamma$-ray spectrometer with a 4000-channel analyzer for $5 \mathrm{~min}$. The second determination of samples was performed after a 20-day cooling using the same spectrometer for $5 \mathrm{~min}$. Short-lived nuclides were analyzed on a horizontal reactor channel equipped with a pneumatic conveyer. The samples were exposed to radiation for $30 \mathrm{sec}$. The first determination was carried out 5 min after radiation, the second $-2 \mathrm{~h}$. In both cases, a Ge( $\mathrm{Li})$-spectrometer with a 1024 channel analyzer was used for $200 \mathrm{sec}$. The results are presented in Table 2. It can be seen that the iron content is especially significant in the organic matter concentrate that can be explained by the fact that the finely dispersed particles of pyrite have been coated and are closely related to the organic matter not separable by the enrichment process. Table 2 also shows the distribution of several elements between organic matter and mineral residue. Zinc and nickel are exclusively related to the organic matter. All in all, abundances of 28 major, minor and trace elements were determined. The numerical values for 26 elements are listed in Table 2.

Table 2

Major, minor and trace elemental abundances in Estonian alum (dictyonema) shale, $g / t$

\begin{tabular}{l|c|c|c|c|c}
\hline Element & $\begin{array}{c}\text { Organic matter } \\
\text { concentrate }\end{array}$ & $\begin{array}{c}\text { Inorganic } \\
\text { residue }\end{array}$ & Element & $\begin{array}{c}\text { Organic matter } \\
\text { concentrate }\end{array}$ & $\begin{array}{c}\text { Inorganic } \\
\text { residue }\end{array}$ \\
\cline { 1 - 2 } $\mathrm{Al}$ & 24000 & 10000 & $\mathrm{Mg}$ & 14000 & 70000 \\
$\mathrm{Sb}$ & 9 & 10 & $\mathrm{Rb}$ & 33 & 240 \\
$\mathrm{As}$ & 110 & 26 & $\mathrm{Sr}$ & 400 & 400 \\
$\mathrm{Ba}$ & 920 & 860 & $\mathrm{Ta}$ & 0.65 & 0.83 \\
$\mathrm{Ce}$ & 130 & 90 & $\mathrm{~Tb}$ & 2500 & 8000 \\
$\mathrm{Cl}$ & 390 & 680 & $\mathrm{Ti}$ & 2500 \\
$\mathrm{Cr}$ & 37 & 78 & $\mathrm{~V}$ & 900 & 1400 \\
$\mathrm{Co}$ & 19 & 12 & $\mathrm{Yb}$ & 3.2 & 3.3 \\
$\mathrm{Cu}$ & 210 & 650 & $\mathrm{Zn}$ & 470 & \\
$\mathrm{Eu}$ & 1.7 & 1.2 & $\mathrm{Mn}$ & 150 & 300 \\
$\mathrm{Hf}$ & 2.3 & 3.6 & $\mathrm{Ni}$ & 310 & \\
$\mathrm{Fe}$ & 58000 & 30000 & $\mathrm{Mo}$ & 600 & 250 \\
$\mathrm{La}$ & 37 & 37 & $\mathrm{Zr}$ & 680 & 640
\end{tabular}


The abundances of $\mathrm{K}$ and $\mathrm{Na}$ in alum shale have been reported earlier [ $\left.{ }^{2}\right]$ and are therefore not given in Table 2. Very often fossil fuels, such as coal, oil shales and peat, are rich in useful major, minor and trace elements, part of which, however, being toxic $(\mathrm{Cd}, \mathrm{Hg}, \mathrm{Pb}, \mathrm{As}, \mathrm{Cr}, \mathrm{Ni}$, V) $\left.{ }^{3}\right]$ as well as in radioactive heavy metal isotopes. While the content of several elements in the raw material (fuel) is relatively low, then in power units on burning their concentration may increase tens of times and they pass to atmosphere in flue gases as fly ash. Fly ash contains substantial amounts of toxic elements that may be detrimental to the environment besides $\mathrm{SO}_{2}$.

Therefore it would be of interest to estimate major, minor and trace elemental abundances in the Estonian and Green River formation oil shales and their ashes. Data pertaining have been given in a report which was presented at the 2nd USA/USSR workshop on health effects of oil shale development, Tallinn, Estonia, USSR, June 22-25, 1981, published in Los Alamos National Laboratory, New Mexico, 1983 (Table 3) [4].

Table 3

Major, minor and trace elemental abundances of Estonian and Green River raw and spent shale solids, g/t [ $\left.{ }^{4}\right]$

\begin{tabular}{|c|c|c|c|c|c|c|}
\hline Element & $\begin{array}{l}\text { Estonian } \\
\text { raw }\end{array}$ & $\begin{array}{c}\text { Estonian } \\
\text { spent }\end{array}$ & $\underset{\text { raw }}{\text { Green River }}$ & $\begin{array}{l}\text { Paraho } \\
\text { spent }\end{array}$ & $\begin{array}{l}\text { Tosco } \\
\text { spent }\end{array}$ & $\begin{array}{l}\text { Occidental } \\
\text { spent }\end{array}$ \\
\hline $\mathrm{Al}$ & 1694 & 2069 & 39430 & 45410 & 9090 & 47300 \\
\hline $\mathrm{Sb}$ & 0.31 & 0.37 & 2.44 & 2.06 & 2.7 & 2.4 \\
\hline As & 4.2 & 11.0 & 42.65 & 41.4 & 66.9 & 31.9 \\
\hline $\mathrm{Ba}$ & 156 & 188 & 0.042 & 7949 & 155 & 658 \\
\hline $\mathrm{Br}$ & 117 & 158 & 0.7 & 1.0 & 2.3 & 4.8 \\
\hline $\mathrm{Ca}$ & 140500 & 296200 & 129500 & 156700 & 157000 & 161800 \\
\hline $\mathrm{Ce}$ & 16.9 & 29.4 & 3.5 & 4.9 & 39.4 & 59 \\
\hline Cs & 1.9 & 2.5 & 4.5 & 2.9 & 4.8 & 3.7 \\
\hline $\mathrm{Cl}$ & 1023 & 1644 & 113.6 & 134 & 62.8 & 130 \\
\hline $\mathrm{Cr}$ & 25.0 & 29.4 & 35.75 & 47.5 & 31.9 & 55 \\
\hline Co & 2.5 & 2.9 & 8.54 & 8.45 & 10.2 & 10.0 \\
\hline $\mathrm{Cu}$ & 61 & 72 & 2486 & 217.3 & 276 & 310.0 \\
\hline Dy & 1.2 & 1.2 & 4.38 & 5.49 & 18.5 & 3.51 \\
\hline Eu & 0.32 & 0.44 & 0.7 & 0.77 & 0.61 & 0.92 \\
\hline $\mathrm{Ga}$ & 0.3 & 0.3 & 12.6 & 13.6 & 0.3 & 49 \\
\hline $\mathrm{Au}$ & $2 \cdot 10^{-5}$ & $2 \cdot 10^{-5}$ & 0.0006 & 0.0007 & $1.4 \cdot 10^{-5}$ & \\
\hline $\mathrm{Hf}$ & 1.3 & 1.5 & 1.7 & 2.1 & 1.5 & 1.6 \\
\hline I & 10.5 & 13.1 & 20.5 & 25.0 & 13.1 & 24 \\
\hline $\mathrm{Fe}$ & 15900 & 27020 & 20660 & 26210 & 18230 & 24700 \\
\hline $\mathrm{La}$ & 1.49 & 2.22 & 20.23 & 24.8 & 4.4 & 27.4 \\
\hline $\mathrm{Lu}$ & $4 \cdot 10^{-2}$ & $8 \cdot 10^{-2}$ & 0.21 & 0.27 & $6 \cdot 10^{-2}$ & 0.13 \\
\hline$M g$ & 15310 & 25590 & 36650 & 43230 & 48910 & 101400 \\
\hline $\mathrm{Mn}$ & 203 & 441 & 430 & 541.2 & 370 & 383 \\
\hline $\mathrm{Hg}$ & $3 \cdot 10^{-2}$ & $5 \cdot 10^{-2}$ & 0.0029 & 0.0022 & 0.097 & 0.03 \\
\hline $\mathrm{K}^{\circ}$ & 11390 & 16400 & 19560 & 23790 & 13380 & 40000 \\
\hline $\mathrm{Rb}$ & 58.7 & 496 & 75.5 & 100.5 & 67.6 & 120 \\
\hline $\mathrm{Sm}$ & $6 \cdot 10^{-3}$ & $6 \cdot 10^{-3}$ & 3.68 & 4.45 & $6 \cdot 10^{-3}$ & 3.7 \\
\hline $\mathrm{Sc}$ & 3.5 & 4.7 & 5.74 & 7.82 & 5.4 & 7.5 \\
\hline Se & 1.8 & 0.8 & 0.27 & 0.25 & 1.9 & 7.3 \\
\hline $\mathrm{Ag}$ & $7 \cdot 10^{-3}$ & $8 \cdot 10^{-3}$ & 2.3 & 2.9 & $7 \cdot 10^{-3}$ & \\
\hline $\mathrm{Na}$ & 384 & 550 & 18670 & 18960 & 17640 & 7200 \\
\hline $\mathrm{Sr}$ & 389 & 0.436 & 623.4 & 791.6 & 0.43 & 1010 \\
\hline $\mathrm{Ta}$ & 0.24 & 0.35 & 0.52 & 0.60 & 0.43 & 1.6 \\
\hline $\mathrm{Tb}$ & 0.20 & 0.31 & 0.49 & 0.54 & 0.30 & 1.8 \\
\hline Th & 4.1 & 3.5 & 6.1 & 7.5 & 4.9 & 8.4 \\
\hline $\mathrm{Ti}$ & 1246 & 1623 & 1842 & 2630 & 984 & 1948 \\
\hline W & $1 \cdot 10^{-3}$ & $2 \cdot 10^{-3}$ & 1.26 & 1.38 & 0.12 & 2.6 \\
\hline $\mathrm{U}$ & 2.12 & 3.06 & 5.59 & 7.28 & 7.50 & 4.77 \\
\hline V & 21.1 & 28.0 & 136.1 & 160.1 & 109 & 113 \\
\hline $\mathrm{Yb}$ & 0.26 & 0.99 & 1.9 & 2.3 & 1.9 & 2.7 \\
\hline $\mathrm{Zn}$ & 6.9 & 3.6 & 47.1 & 49.3 & 3.4 & 175 \\
\hline
\end{tabular}


A comparison of Estonian and Green River Formation shales demonstrated that the abundances of major elements, such as $\mathrm{Al}, \mathrm{Mg}, \mathrm{Na}, \mathrm{K}$, are several times higher in the latter. The Estonian oil shale has lower concentrations of $\mathrm{Ba}$ and $\mathrm{Sr}$, trace elements (As, Co), rare earths, and $\mathrm{U}, \mathrm{V}$, $\mathrm{Zn}$.

The Estonian oil shale ash contains $\mathrm{Ca}$ twice as much as that of oil shale from the deposits of Paraho, Tosco and Occidentals.

The Green River formation shale is richer in clay minerals. Of major components $\mathrm{C}, \mathrm{O}, \mathrm{Si}^{\prime}$ and $\mathrm{S}$, and of minor ones $\mathrm{Pb}$ cannot be identified by INAA due to their intensivity [ $\left.{ }^{4}\right]$. However, the authors of this report, E. J. Peterson and W. D. Spall [4], note that only two Estonian oil shale samples (raw and spent shale) with unknown histories were examined. We are of the opinion that the Estonian raw shale sample may originate from bed $\mathrm{E}$ or B, judging by its high Fisher Assay oil yield.

The methods of INAA and energy dispersive X-ray fluorescence analysis (XRF) are applicable to determining not only minor and trace elemental abundances, but also liquids, in our case to trace elements in oil shale. So, C. L. Wilkerson [5] has evaluated abundances of 26 trace elements in the raw and filtrated oil obtained by pyrolysis of the Green River shale (Fe, As, Mg, Ni, K, Ti, Ca, Sr, Zn, Co, Mo, Na, Cu, Cl, Se, $\mathrm{Pb}, \mathrm{V}, \mathrm{Rb}, \mathrm{Ga}, \mathrm{Hg}, \mathrm{Al}, \mathrm{Br}, \mathrm{Cr}, \mathrm{Mn}, \mathrm{Yb}, \mathrm{U})$ their distribution between oil shale fractions and relationship with organic matter.

A thorough review of major, minor and trace elemental abundances in oil shale and oil shale ashes of the oil shale fired Baltic Power Plant has been given in [ $\left.{ }^{6}\right]$. It could be seen that abundances of several minor elements, such as $\mathrm{Pb}, \mathrm{Cl}, \mathrm{Rb}, \mathrm{Zn}, \mathrm{As}$ etc. increased severalfold in oil shale ashes and fly ash.

All in all, abundances of 11 major components and 21 minor ones were determined by using INAA and XRF [ $\left.{ }^{6}\right]$.

The results obtained and literature data are indicative of the applicability of INAA not only to the determination of major, minor and trace elemental abundances in minerals, but also to the investigation of technological processes (e. g. minerals enrichment) and fuels. Nowadays, however, mainly quantitative methods of analysis are being used to determine major elemental abundances in minerals and fossil fuels.

The authors wish to thank the leadership of the Institute of Physics, the Latvian SSR Academy of Sciences, for enabling us to carry out this research work.

\section{REFERENCES}

1. Пелекис З. Э., Пелекис Л. Л., Тауре И. Я., Липпмаа Э. Т., Маремяэ Э. Я., Пихлак $A$. A. Инструментальное нейтронно-активационное определение состава проб фосфоритовых руд, диктнонемовых сланцев и других природных объектов Эстонской ССР. - Изв. АН ЛатвССР. Сер. физ. и техн. н., 1984, № 1, 3-8.

2. Пелекис Л., Пелекис З., Тауре И., Киррет О., Раявее Э. Инструментальный нейтронно-активационный анализ диктионемового сланца Маардуского месторождения. - Изв. АН ЭССР. Хим., 1985, 34, № 3, 161-163.

3. Larjava, K., Áijälä, M., Mojtahedi, W. Savukaasujen raskasmetallipäästöjen vähentäminen. - Kemia, 1986, N 9, 712-716.

4. Peterson, E. J., Spall, W. D. Physical and Chemical Characterization and Comparison of Solids, Liquids, and Oils from Estonian and Green River Formation Shales, Los Alamos National Laboratory. Los Alamos (New Mexico), 1983.

5. Wilkerson, C. L. Trace metal composition of Green River retorted shale oil. - Fuel, 1982, 61, January, 63-70.

6. Пец Л. И., Ваганов П. А., Кнот И., Халдна Ю. Л., Швенке Т., Шнир К., Юга Р. Я. Микроэлементы в золах сланца-кукерсита Прибалтийской ГРЭС. - Горючие сланцы, 1985, 2, № 4, 379-389.

Academy of Sciences of the Latvian SSR, Institute of Physics

Academy of Sciences of the Estonian SSR, Institute of Chemistry 
L. PELEKIS I, O. KIRRET, I. TAURE, Zane PELEKIS,

G. EGLIT, E. RAJAVEE, V. AHELIK

\section{EESTI DIKTUOONEEMAKILDA JA MÓNEDE PÓLEVKIVIDE INSTRUMENTAAL-NEUTRONAKTIVATSIOONIANALOUS}

Autorid on määranud eesti diktüoneemakilda rikastatud proovis sisalduvaid makro-, mikro- ja jälgelemente instrumentaal-neutronaktivatsioonianalüüsi meetodil. Võrdluseks on toodud kirjanduse andmeid mõnede põlevkivide makro-, mikro- ja jälgelementse koostise kohta, mille määramisel on kasutatud sama meetodit.

Л. ПЕЛЕКИС|, О. КИРРЕТ, И. ТАУРЕ, Зане ПЕЛЕКИС,

Г. ЭГЛИТ, Э. РАЯВЕЕ, В. АХЕЛИК

\section{ИНСТРУМЕНТАЛЬНЫИ НЕИТРОННО-АКТИВАЦИОННЫИ АНАЛИЗ ЭСТОНСКОГО ДИКТИОНЕМОВОГО СЛАНЦА И НЕКОТОРЫХ ДРУГИХ ГОРЮЧИХ СЛАНЦЕВ}

В пробе обогащенного диктионемового сланца и в его минеральном остатке определено содержание 28 элементов, присутствующих в макро-, микро- и следовых количествах. Полученные результаты сравнены с данными по горючим сланцам некоторых других месторождений. 